\title{
Effect of Herbal Medicine Supplementations (Arsilvon Super, Bedgen40 and Hepa-cure Herbal Medicines) on Growth Performance, Immunity and Haematological Profile in Broilers
}

\author{
Sajid Hussain Qamar ${ }^{1, *}$, Ahsan ul Haq ${ }^{1}$, Naeem Asghar ${ }^{1}$, Shahid ur Rehman ${ }^{1}$, Pervez Akhtar ${ }^{2}$, \\ Ghulam Abbas ${ }^{1}$ \\ ${ }^{1}$ Department of Poultry Science, University of agriculture, Faisalabad, Pakistan \\ ${ }^{2}$ Department of Animal Breeding and Genetics, University of agriculture, Faisalabad, Pakistan
}

Copyright $(\subset) 2015$ Horizon Research Publishing All rights reserved.

\begin{abstract}
The experiment was conducted at Poultry Research center University of Agriculture Faisalabad to evaluate the Arsilvon super, Bedgen40 and Hepa-Cure herbal medicines on broiler performance, immunity and hematology. For this study one hundred eighty day old broiler chicks were purchased from local hatchery and were reared in a group for one week. After one week, one hundred twenty broiler chicks of middle weight range were picked up randomly and divided into 12 experimental units $(10$ chicks/each).These units were allotted to 4 groups A, B, C, and $\mathrm{D}$ such that $\mathrm{A}$ group served as control without any supplementation, group B was supplemented with Arsilvon super @ $1 \mathrm{ml} / \mathrm{L}$, group $\mathrm{C}$ was supplemented with Bedgen 40 (a) $0.5 \mathrm{ml} / 4 \mathrm{~L}$, and D was supplemented with Hepa-cure @ $1 \mathrm{ml} / \mathrm{L}$ in drinking water. Supplementation of herbal medicine exhibited significant $(\mathrm{P}<0.05)$ effects on weight gain, Feed Conversion Ratio and non-significant effect on feed consumption ( $\mathrm{P}>0.05$ ). Supplementation of herbal medicines showed significant treatment effect against the Newcastle disease but non-significant effect against the Infectious bursal disease. Herbal medicines revealed significant effects on blood glucose and red blood cells, but showed non-significant effect on cholesterol, hemoglobin, white blood cells and packed cell volume. In conclusion, herbal medicine supplementations in broiler revealed positive effect on performance, immunity and hematological parameters.
\end{abstract}

Keywords Herbal Medicines, Broiler, Feed Conversion Ratio, Newcastle Disease, Infectious Bursal Disease, Blood Profile

\section{Introduction}

Poultry sector is passing through a period of using antibiotics for the treatment of diseases and also as growth promoters but it leads to the production of antibiotic resistant cells [12] due to residual effect of antibiotics. It was estimated that 4500 tons of antibiotics used in the world as growth promoter per year. Approximately $80 \%$ of domestic animals have been fed with synthetic (antibiotics) compounds for the purpose of medication and as growth promoter. There have been much more discussions on the utilization of antibiotics in the world. There is need to find more efficient alternatives or combinations of different alternatives for maintaining health and improving performance of poultry and other livestock species. Phytogenic compounds are the groups of feed additives that have been reported to possess a potential for growth enhancement of poultry due to presence of a number of pharmacologically active substances. They are supposed to enhance feed intake, activate digestive enzymes and stimulate immune function.

Antibiotic growth promoters (AGP) have been very helpful to enhance the growth performance and feed conversion ratio of poultry birds [19]. However, constant use of antibiotics in poultry may result in residual effects in poultry products which may cause the bacterial resistance against treatments in human body. Due to these deleterious effects to human health, use of antibiotics in poultry was completely banned by European Union since 2006 [25]. At present prevalent infectious diseases are major problem to the whole world which causes the financial failure to the poultry owners and farmers. In addition, other factors in which vaccination failure, infection by immune-oppressive diseases, and misuse of antibiotics can cause immunodeficiency.

After the ban on antibiotics by European Union in 2006 in poultry, there was need to find the alternatives or 
replacement to antibiotics. Many feed additives such as prebiotics, probiotics, symbiotic, organic acids and herbal growth promoters are used as replacement of antibiotics having the activity against pathogenic microorganism and to enhance the growth of useful microorganism [7].

The history of herbs is too long as the mankind; these plants were used from the beginning of the world. Many wars have been fought and lands occupied for the purpose of plants and herbs, and even at yet human continuous depend on exotic species for many of our latest medicines and chemicals [27]. Recently, many countries tended to minimize or prohibit the chemical components due to deleterious side effects on both animals and human. So, it is important to use natural promoters [15].

Photogenic feed additives are supposed to help regular digestion while improving performance along with various other way of action including reducing bacterial colony counts and fermentation products, decreasing the activity of gut associated lymphatic system, boosting pre- cecal nutrient digestibility, and keeping anti-oxidative properties. Limited research found which structured to growth promoting effects of photogenic feed additives in poultry. However, Buchanan et al. (2008) stated that broiler chicken fed diets having plant extract blends had minimum feed conversion ratio, increase weight gain, and maximum breast yield [6]. Windisch et al. [36] completed a broad review about phytogenic feed additives and planned modes of actions of these products.

Herbs, plant extracts and species can be valuable alternatives for the health and nutrition of the chicken. They have a wide range of activities such as stimulation of feed intake and endogenous secretions or have antimicrobial, coccdiostatic or anathematic activity. Plants have evolved a wide range of secondary metabolites. Most of the active secondary metabolites of the plant with classes of isoprene byproducts, flavonoides and a large number of mixtures have advised functions as alternative to antibiotics or as antioxidants in vivo as well as in feed.

There is a variety of herbal based medicines in the markets which are the mixture of different herbs and can be successfully use in poultry. Therefore a project has been planned to evaluate the effect of herbal based products i.e. Arsilvon super, Bedgen 40 and Hepacure on growth performance, immune response and hematological response in broilers.

\section{Material and Methods}

The research project was conducted at Poultry Research Center, University of Agriculture, Faisalabad. Day-old chicks $(n=220)$ were purchased and reared in a groups for seven days as adaptation period. At $8^{\text {th }}$ day of age, these chicks were individually weighed and 120 chicks of middle weight range were selected to be used as experimental birds. The selected chicks were distributed in 12 replicates (10 birds/ replicate) and were further allotted to four treatment groups (A, B, C and D) such that each group received three replicates. Two rations (starter and finisher) were prepared and fed to the experimental birds. The chemical composition of the experimental rations along with proportion of ingredients (purchased locally) used are presented in Table 1. The starter and finisher rations were fed ad libitum to all treatment groups, from 1-21 and 22-35 days of age, respectively. Herbal medicine plan for the experimental birds is shown in Table 2. Each experimental unit of the chicks was reared in a separate pen. The birds were kept under similar managerial conditions like space, light, temperature, ventilation and relative humidity. Fresh and clean water was available to the birds at all the times. All the birds were vaccinated according to the recommended schedule.

The data collected were comprised of initial body weight, weekly body weight gain, weekly feed consumption, feed conversion ratio (feed intake/weight gain), daily water intake, and mortality to check performance of birds. Blood samples ( 2 birds/ replicate) were collected at $28^{\text {nd }}$ and $32^{\text {th }}$ day of age to determine the immune response against the ND and IBD and blood profile (Packed Cell Volume, Hemoglobin level, WBCs count and RBCs count) [18,28]. The results obtained from the trial were statistically analyzed using Analysis of Variance Technique under Completely Randomized Design. Treatment means were compared by Least Significance Difference [31] and economics of production of each treatment was calculated at the end of the trial.

Table 1. Proportion and compositions of ingredients used in experimental rations

\begin{tabular}{|c|c|c|}
\hline Ingredients & Starter Ration (\%) & Finisher Ration (\%) \\
\hline Maize & 36 & 35 \\
\hline Wheat & 10 & 10 \\
\hline Rice polish & 5 & 5 \\
\hline Rice broken & 5 & 8 \\
\hline Wheat bran & 3 & 6 \\
\hline Guar meal & 3 & 2 \\
\hline Sunflower meal & 6 & 5 \\
\hline Corn gluten $60 \%$ & 6 & 5 \\
\hline Soybean meal & 10 & 10 \\
\hline Fish meal & 8 & 6 \\
\hline Soya oil & 3 & 3 \\
\hline Molasses & 3 & 3 \\
\hline Lime stone & 1.16 & 1.16 \\
\hline $\begin{array}{c}\text { Mono \& di-calcium } \\
\text { phosphate }\end{array}$ & 0.167 & 0.167 \\
\hline Pre-mix & 0.5 & 0.5 \\
\hline Salt & 0.173 & 0.173 \\
\hline Total & 100 & 100 \\
\hline
\end{tabular}

\begin{tabular}{|c|c|c|}
\hline \multicolumn{3}{|c|}{ Chemical composition } \\
\hline Crude protein & $22 \%$ & $20 \%$ \\
\hline Metabolizable energy & $3100 \mathrm{Kcal} / \mathrm{Kg}$ & $3000 \mathrm{Kcal} / \mathrm{Kg}$ \\
\hline Crude fiber & $4.18 \%$ & $4.55 \%$ \\
\hline
\end{tabular}


Table 2. Herbal medicinal plan

\begin{tabular}{|c|c|}
\hline Groups & Treatments \\
\hline Group A (Control) & $\begin{array}{c}\text { Offered drinking water without any } \\
\text { supplementation }\end{array}$ \\
\hline Group B (Arsilvon super) & $\begin{array}{c}\text { Offered drinking water supplemented } \\
\text { with Arsilvon super medicine @ 1 ml/L }\end{array}$ \\
\hline Group C (Bedgen 40) & $\begin{array}{c}\text { Offered drinking water supplemented } \\
\text { with Bedgen 40 medicine @ 0.5ml/4L }\end{array}$ \\
\hline Group D (Hepa-cure) & $\begin{array}{c}\text { Offered drinking water supplemented } \\
\text { with Hepa-cure medicine @ 1ml/L }\end{array}$ \\
\hline
\end{tabular}

Values within the same row which have different superscripts are significantly different $(\mathrm{P}<0.05)$

\section{Results}

\section{Performance parameters}

Statistical analysis of the data did not showed any significant effect of supplementation of herbal medicines on feed intake of broilers. The average weight gain per chicks at the end of trial under treatment A (control), B (Arsilvon super), C (Bedgen 40) and D (Hepa-cure) were1763, 1915, 1843 and 1906 gm, respectively. The maximum weight gain was observed in B followed by the treatment D, C and A, respectively. Statistical analysis of data revealed that addition of various herbal medicine exhibited significant $(\mathrm{P}<0.05)$ effects on weight gain of the birds of all treatment groups as compared to those of control group. The feed conversion ratio under different treatments i.e. A (control), B (Arsilvon super), C (Bedgen 40) and D (Hepa-cure)were 1.91, $1.68,1.82$ and 1.78 , respectively. Best feed conversion ratio was found in B followed by D, C and A respectively. Statistical analysis of data revealed that supplementation of Arsilvon super, Bedgen 40 and Hepa-cure in drinking water offered to broiler exerted a significant $(\mathrm{P}<0.05)$ effect on FCR of broilers (Table 3 ). Up to 35 days of age the overall mortality of chicks under different treatments was also recorded during the study period. The number of birds died under different treatments i.e. A, B, C and D were $1,0,0$ and 2 respectively.

\section{Immune Response}

The average values of ND antibody titer under different treatments A (control), B (Arsilvon super), C (Bedgen40) and D (Hepa-cure) were 74.66, 277.33, 256 and 320, respectively. The maximum value of ND antibody titer was found in treatment D followed by B, C and A respectively. Statistical analysis of the data showed that supplementation of herbal products Arsilvon super, Bedgen 40 and Hepa-cure in drinking water showed a significant $(\mathrm{P}<0.05)$ effect on antibody titer against ND in broilers. However, addition of different herbal products (Arsilvon super, Bedgen 40 and Hepa-cure) did not show any significant effect on antibody titers against Infectious bursal disease in broilers (Table 4).

Table 3. Evaluation of herbal Medicine Arsilvon Super, Bedgen 40 and Hepa-cure on weight gain, feed consumption and feed conversion ratio of broilers during 2-5 weeks

\begin{tabular}{|c|c|c|c|c|c|c|}
\hline \multirow[b]{2}{*}{ Variables } & \multicolumn{4}{|c|}{ Treatment } & \multirow[b]{2}{*}{ SEM } & \multirow[b]{2}{*}{$\mathrm{P}$ value } \\
\hline & $\begin{array}{c}\text { A } \\
\text { (Control) }\end{array}$ & $\begin{array}{c}\text { B } \\
\text { (Arsilvon } \\
\text { super@1ml/L) }\end{array}$ & $\begin{array}{c}\mathrm{C} \\
\text { (Bedgen40@) } \\
0.5 \mathrm{ml} / 4 \mathrm{~L}) \\
\end{array}$ & $\begin{array}{c}\mathrm{D} \\
\text { (Hepa-cure } \\
(1 \mathrm{ml} / \mathrm{L}) \\
\end{array}$ & & \\
\hline Number of Birds & 30 & 30 & 30 & 30 & & \\
\hline Initial body weight (g) & 160 & 155 & 157 & 161 & & \\
\hline Final body weight gain (g) & $1923^{b}$ & $2070^{\mathrm{a}}$ & $2000^{\mathrm{ab}}$ & $2067^{\mathrm{a}}$ & 34.66 & \\
\hline Weight gain (g) & $1763^{\mathrm{b}}$ & $1915^{\mathrm{a}}$ & $1843^{\mathrm{ab}}$ & $1906^{\mathrm{a}}$ & 35.11 & 0.008 \\
\hline Feed consumption (g) & 3364 & 3224 & 3354 & 3401 & 38.59 & 0.635 \\
\hline Feed conversion ratio & $1.91^{\mathrm{c}}$ & $1.68^{\mathrm{a}}$ & $1.82^{\mathrm{b}}$ & $1.78^{\mathrm{ab}}$ & 0.047 & 0.006 \\
\hline Mortality & 1 & 0 & 0 & 2 & & \\
\hline
\end{tabular}

Values within the same row which have different superscripts are significantly different $(\mathrm{P}<0.05)$

Table 4. Antibody titer of broilers against Newcastle and Infectious Bursal disease supplemented with Arsilvon super, Bedgen 40 and Heap-cure herbal medicines

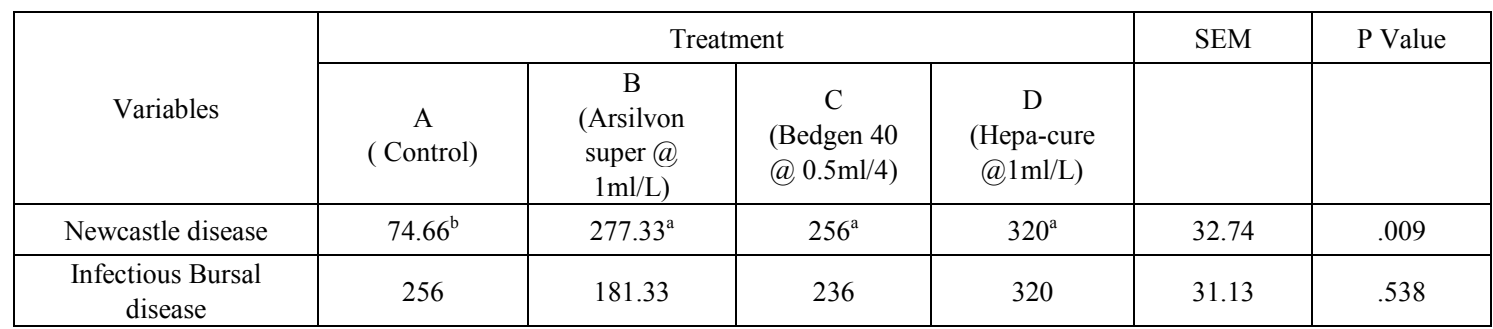

Values within the same row which have different superscripts are significantly different $(\mathrm{P}<0.05)$ 

on Growth Performance, Immunity and Haematological Profile in Broilers

Table 5. Hematological values of broilers supplemented with Arsilvon super, Bedgen 40 and Heap-cure herbal medicines

\begin{tabular}{|c|c|c|c|c|c|c|}
\hline \multirow[b]{2}{*}{ Variables } & \multicolumn{4}{|c|}{ Treatments } & \multirow[t]{2}{*}{ SEM } & \multirow[t]{2}{*}{$\mathrm{P}$ Value } \\
\hline & $\begin{array}{c}\text { A } \\
\text { ( Control) }\end{array}$ & $\begin{array}{c}\text { B } \\
\text { (Arsilvon Super } \\
\text { @ } 1 \mathrm{ml} / \mathrm{L})\end{array}$ & $\begin{array}{c}\mathrm{C} \\
\text { (Bedgen } 40 @ \\
0.5 \mathrm{ml} / 4 \mathrm{~L})\end{array}$ & $\begin{array}{c}\mathrm{D} \\
\text { (Hepa-cure @ } \\
1 \mathrm{ml} / \mathrm{L})\end{array}$ & & \\
\hline $\begin{array}{c}\text { Blood Glucose } \\
(\mathrm{mg} / \mathrm{dl})\end{array}$ & $166.66^{\mathrm{b}}$ & $153.66^{\mathrm{a}}$ & $129^{\mathrm{a}}$ & $149.66^{\mathrm{a}}$ & 12.86 & .002 \\
\hline Cholesterol(mg/dl) & 174.33 & 164.33 & 154.33 & 170 & 4.13 & .393 \\
\hline Hemoglobin (g/dl) & 9.63 & 9.73 & 8.73 & 11.26 & 0.62 & .603 \\
\hline $\begin{array}{l}\text { Red blood cells } \\
\left.\text { (RBC's } x 10^{6} / \mu \mathrm{L}\right)\end{array}$ & $2.44^{\mathrm{a}}$ & $2.05^{\mathrm{a}}$ & $1.20^{\mathrm{b}}$ & $2.32^{\mathrm{a}}$ & 0.17 & .018 \\
\hline $\begin{array}{l}\text { White blood cells } \\
\text { (WBC's } \times 10^{3} / \mu \mathrm{L} \text { ) }\end{array}$ & 12926 & 15073 & 12926 & 14993 & 4.63 & .105 \\
\hline $\begin{array}{l}\text { Packed cell volume } \\
\text { (PCV \%) }\end{array}$ & 30.20 & 30.37 & 25.68 & 34.25 & 2.09 & .617 \\
\hline
\end{tabular}

\section{Hematology}

Statistical Analysis of the data revealed that addition of commercial herbal products in drinking water, significantly $(\mathrm{P}<0.05)$ decreased blood glucose levels of the birds. The mean values of blood glucose under different treatments $A$ (control), B (Arsilvon super), C (Bedgen40) and D (Hepa-cure) were $166.66,153.66,129$ and $149.66 \mathrm{mg} / \mathrm{dl}$, respectively. Statistical Analysis of the data revealed non-significant effect of herbal medicines on cholesterol level, hemoglobin, packed cell volume and white blood cell count in broilers. However, analysis of variance of the data exhibited significant $(\mathrm{P}<0.05)$ effect of herbal medicines supplementation on red blood cell count in broiler.

\section{Discussion}

\section{Performance}

The present study showed that the supplementation of herbal medicines Arsilvon super, Bedgen 40 and Hepa-cure broilers revealed non-significant effect on feed consumption of broilers. The result of this study are compatible with the findings of Banjo (2012) who did not revealed any significant improvement in feed consumption due to dietary inclusion of Moringa oleifera leaf meal in broiler diet when compared with those fed diet without any supplementation (control) [2]. These results are similar with Gadziraye et al. (2012) and Ocak et al., (2008) who reported that by the supplementation of ginger, Moringa olifera and garlic there was no significant difference in the feed consumption of the broiler among the different treatment. [11,22]

Supplementation of herbal medicines Arsilvon super, Bedgen 40 and Hepa-cure herbal growth promoters improved FCR values in the broilers. Better FCR may probably be due to improved digestibility of nutrients, because herbs and herbal products can control and bound the growth and colonization of several pathogenic and nonpathogenic species of bacteria in chicken gut. This may lead to a better efficiency in the consumption of feed, resulting in improved growth and feed efficiency [3]. The phenolic compounds of nettle like carvacrol and thymol exhibited considerable antimicrobial and antifungicidal activity [14]. Another probable cause of better FCR may the good nutritional value of Azadirachta indica and Berberis vulgaris [32], Moringa oleifera [24] and Cichorium intybus and Mentha pepriminta [5], good nutritional value might have increased weight gain of the birds in the present study. These findings are compatible with those observed by Nidaullah et al. (2010), Portugaliza and Fernandez (2012) who reported improved FCR in broilers offered drinking water supplemented with different herbal plants infusion $[21,26]$. Similarly Wheeler (2006), who fed herbal medicines to broiler chicken and observed better FCR values at the end of the trial [35].

\section{Immunity}

Immune system is the most important system of the body that helps to maintain health. It is made up of tissues, lymph nodes and cells, and is principally designed to kill or inhibit the growth of infection causing organisms. When the immune system or defense system of the body does not work properly then chances of disease outbreak increases which may lead to high economic losses. Supplementation of herbal medicines in drinking water significantly $(\mathrm{P}<0.05)$ increased the antibody titer against ND in the broilers used in this study. The maximum level of antibody titer against ND was in birds of group D offered drinking water supplemented with Hepa-cure may probably be due to the presence of Hypericum perfortum extract a major constituent of Hepa-cure which is known to have antiviral properties that might have reduced in pathogens and thus helped in boosting immunity. Another possible reason of increased level of antibody titer against ND in the birds may be due to increased activity of neutrophils in blood after vaccination, which could play a major role in body immunity production [13]. Similar results have also been observed by Zafar et al., (2011) [37]. Supplementation of herbal medicines in drinking water did not exhibit any significant effect on antibody titer against Infectious Bursal disease in the broilers. The results of the present study are compatible with those observed by Dorman and Deans (2000) and Fallah et al. (2013) $[8,10]$. 


\section{Hematology}

Supplementation of herbal medicines in drinking water significantly $(\mathrm{P}<0.05)$ lowered the blood glucose level of broilers. The reduction in glucose level might be due to the suppressive effect of herbal plants leaf extracts in the commercial products/solutions on glucagon, which otherwise increases blood glucose in chickens, thereby maintaining blood glucose homeostasis. The results of the present study are in agreement with the findings of Saeid et al. (2010) who observed significantly decreased serum glucose in broilers supplemented with aqueous extract of ginger@0.4 and 0.6\% [29].

Supplementation of herbal medicines in drinking water did not exert any significant effect on blood hemoglobin level, cholesterol level, packed cell volume and white blood cell count of birds. Khosravi et al. (2008) reported that the addition of nettle extract to a broiler diet had no significant positive effect on total cholesterol [17]. Barazesh et al., (2013) studied the influence of supplementation of ginseng root powder in diet of broilers on blood hematology and found that the level of hemoglobin remained unaffected [1]. Similar findings have also been observed by Toghyani et al. (2010) in chicken fed garlic @ 0.3\% [33]. Fluctuations in red blood cell value of avian blood are normal phenomenon and may be associated with the physiological status of the birds reported by Ogbe and Affiku (2013) [23].

The results of the present study are similar with those observed by Olugbemi et al. (2010) who reported that red blood cell count decreased due to the supplementation Moring oleifera leaf meal in cassava based diet in broilers [24]. Similar findings have been observed by Zanu et al. (2012) in chicken fed Neem leaf meal which did not revealed any effect on red blood cell count in broilers [38]. Supplementation of herbal medicines Arsilvon super, Bedgen 40 and Hepa-cure in drinking water did not exhibit any effect on number of WBCs in broilers of treated groups. The results of the present study are compatible with those observed by Sharifi et al. (2013) who reported that white blood cells count was not affected significantly due to the dietary inclusion of a combination of dried herbs (peppermint, cumin, neem and thymol) @ 2g/Kg diet [30]. Findings of Zanu et al. (2012) are also in line with those observed in the present study, who reported that various levels of Thymus vulgaris extract in drinking water did not show any difference in the white blood cell count in broilers [38].

Supplementation of herbal medicines did not exhibit any significant effect on PCV value of broilers. These results are compatible with those observed by Kannan et al. (2005) who reported that supplementation of oil extract derived from herbal plants (thyme and cinnamon) in drinking water of broilers did not influence their PCV value [16]. Tollba and Hassan (2003) also reported similar observations of addition of polyherbal aqueous extract of black pepper (Piper nigrum), nishyinda (Vitex negundo) leaves, and cinnamon (Cinnamomum verum) in drinking water, in comparison with an antibiotic in broilers [34].

\section{Economics of the production}

Average cost of production per broiler kept under different experimental groups (A, B, C and D) was Rs. 224.38, 225.08, 235.93 and 234.045, respectively (Table 6). Labor cost not include in this because the experiment was conducted at Poultry Research Center, University of Agriculture, Faisalabad. Miscellaneous cost was calculated by including the estimated cost of electricity, gas, litter, disinfectants and vaccination which was found to be Rs. 20/bird. The average live weight in experimental groups A, $\mathrm{B}, \mathrm{C}$ and $\mathrm{D}$ was $1.763,1.915,1.843$ and $1.906 \mathrm{Kg}$, respectively. The birds were sold on the basis of live weight at the rate of Rs. 130 per $\mathrm{Kg}$. The net profit on per $\mathrm{Kg}$ live weight basis was higher in the birds of experimental group which were treated with Arsilvon Super as compared to other treatment groups; whereas, the lowest profit was gained from the birds in group $\mathrm{C}$.

Table 6. Data showing economics of broiler production kept under different treatment groups supplementing with herbals medicines in water from $1^{\text {st }}$ to $35^{\text {th }}$ day of age

\begin{tabular}{|c|c|c|c|c|}
\hline \multirow[b]{2}{*}{ Variables } & \multicolumn{4}{|c|}{ Treatment } \\
\hline & $\begin{array}{c}\text { A } \\
\text { (Control) }\end{array}$ & $\begin{array}{c}\text { B } \\
\text { (Arsilvon super } \\
\text { @ } 1 \mathrm{ml} / \mathrm{L})\end{array}$ & $\begin{array}{c}\mathrm{C} \\
\text { (Bedgen } 40 \\
(0.5 \mathrm{ml} / 4 \mathrm{~L})\end{array}$ & $\begin{array}{c}\text { D } \\
(\text { Hepa-cure } @ 1 \mathrm{ml} / \mathrm{L})\end{array}$ \\
\hline Chick cost (Rs.) & 53 & 53 & 53 & 53 \\
\hline Total feed consumed/bird (Kg) & 3.364 & 3.224 & 3.354 & 3.401 \\
\hline Feed cost/Kg (Rs.) & 45 & 45 & 45 & 45 \\
\hline Feed cost/bird (Rs.) & 151.38 & 145.08 & 150.93 & 153.045 \\
\hline Medicine cost & 0 & 7 & 12 & 8 \\
\hline *Miscellaneous charges/ bird (Rs.) & 20 & 20 & 20 & 20 \\
\hline Total cost/bird (Rs.) & 224.38 & 225.08 & 235.93 & 234.045 \\
\hline Average live weight gain/bird $(\mathrm{Kg})$ & 1.763 & 1.915 & 1.843 & 1.906 \\
\hline Sale price/Kg live (Rs.) & 130.00 & 130.00 & 130.00 & 130.00 \\
\hline Sale price/bird (Rs.) & 229.19 & 248.95 & 239.59 & 247.78 \\
\hline Net profit/bird (Rs.) & 4.81 & 23.87 & 3.66 & 13.735 \\
\hline
\end{tabular}

* Miscellaneous includes brooding cost, cost of litter, disinfection and vaccination 
The replacement of antibiotic growth promoters with herbal medicines exhibited their effect on profit margin of the broilers. The birds using water supplemented with Arsilvon Super fetched the maximum profit in all treatment groups. The results of the present study are in line with the findings of Durrani et al. (2008) who reported that supplementation of Herbal infusion increased profit margin in broiler when compared to non-supplemented group [9]. Similarly, Zanu et al. (2012) reported that dietary inclusion of Moringa oleifera leaf meal (MOLM) in the rations was more beneficial in terms of profit margin in broiler production than those fed ration without MOLM supplementation [38]. Behboud et al. (2011) also reported a reduction in the cost of feed consumed at higher inclusion level of chicory leaf pulp, which ultimately reduced cost of production of broiler [4].

\section{Conclusions}

It was concluded from the results of the study that supplementation of herbal medicines (Arsilvon super, Bedgen 40 and Hepa-cure) in drinking water revealed better performance in broilers like weight gain, feed consumption, efficiency of feed utilization, stabilization of serum metabolites with better immune response and improved some blood biochemistry.

\section{Recommendations}

Based upon the results of the study, the birds given water supplemented with herbal medicines showed better performance results along with increased profit margin when they are compared to control groups. Therefore, use of commercial herbal product Arsilvon Superis recommended to be used in broiler production as an inexpensive and efficient herbal growth promoter without any residual or harmful effects, in place of antibiotic growth promoter.

\section{REFERENCES}

[1] Barazesh, H., M. B. Pour, S. Salari and T. M. Abadi. 2013. The effect of ginger powder on performance, carcass characteristics and blood parameters of broilers. Int. J. Adv. Biol. Biomedi. Res. 1: 1645-1651.

[2] Banjo, O.S. 2012.Growth and Performance as affected by inclusion of Moringa oleifera leaf meal in Broiler chicks diet. Journal of Biology, Agriculture and Healthcare www.iiste.org ISSN 2224-3208 (Paper) ISSN 2225-093X (Online). 2: 35-39.

[3] Bedford, M. 2000. Removal of antibiotic growth promoters from poultry diets: implications and strategies to minimise subsequent problems. World's Poultry Science Journal 56: 347-365.

[4] Behboud, J., R. Ali and H. Elmira. 2011. Comparative effect of Chicory (Cichorium intybus L.) and Nigella sativa extract with an antibiotic on different parameters of broiler chickens. J. Appl. Environ. Biol. Sci. 1: 525-528

[5] Belesky, D. P., K. E. Turner, J. M. Fedders and J. M. Ruckle. 2010. Mineral composition of swards containing forage chicory. J. Agron. 93: 468-475.

[6] Buchanan N. P., J. Hott, S. Cutlip, A. Rack, A. Asamer and J. Moritz. (2008). The effects of a natural antibiotic alternative and a natural growth promoter feed additive on broiler performance and carcass quality. J. Appl. Poult. Res. 17, 202-210.

[7] Chaudhary, M.T. 2012. Effect of supplementation of citric acid in broiler performance. M.sc (Hons) Thesis department of poultry science, university of agriculture Faisalabad.

[8] Dorman H. J. D. and Deans S. G. 2000. Antimicrobial agents from plants: antibacterial activity of plant volatile oils. J. Appl. Microbiol. 88: 308-316.

[9] Durrani, F.R., N. Chand, M. Jan, A. Sultan, Z. Durrani and S. Akhtar. 2008. Immunomodulatory and growth promoting effect of Azadirachta indica leaves infusion in broiler chicks. Sarhad J. Agric. 24(4): 655-659.

[10] Fallah, R., A. Kiani and A. Azarfar. 2013. Effect of artichoke leaves meal and mentha extract on immune cells and blood biochemical parameters of broilers. Glob. Vet. 10: 99-102.

[11] Gadzirayi , C. T., B. Masamha, J. F. Mupangwa and S. Washaya . 2012. Performance of Broiler Chickens Fed on Mature Moringa oleifera Leaf Meal as a Protein Supplement to Soyabean Meal. Int. J. Poult. Sci. 11: 5-10.

[12] Gauer, R. V. 2004. Drug free diet performance optimized by nutritional programs. World poult. 20:14-15.

[13] Guo, F. C., B. A. Williams, R. P. Kwakkel and M. W. A. Verstegen. 2003. In vitro fermentation characteristics of two mushrooms, an herb and their polysaccharide fractions, using chicken cecal contents asinoculum. Poult. Sci., 82: 608-61.

[14] Gulcin, I., O. 'I. Kufrevioglu, M. Oktay, M. E. Buyukokuroglu. 2004. Antioxidant, antimicrobial, antiulcer and analgesic activities of nettle (Urtica dioica L.). J. Ethnopharm. 90: 205-215.

[15] Hassan, I. I., A. A. Askar and G. A. El-Shourbagy. 2004. Influence of some medicinal plants on performance ; physiological and meat quality traits of broiler chicks. Egypt. Poult. Sci., 24 :247-266.

[16] Kannan, M., R. Karunakaran, V. Balakrishnan and T. G. Prabhakar 2005. Influence of prebiotics supplementation on lipid profile of broilers. Int. J. Poult. Sci. 4: 994-997.

[17] Khosravi A., Boldaji F., Dastar B. and Hasani S. (2008). The use of some feed additives as growth promoter in broilers nutrition. Int. J. Poult. Sci. 7, 1095-1099.

[18] MAFF, ADAS. 1984. Manual of Veterinary Investigation. Vol. 2, $3^{\text {rd }}$ ed. Reference book., Her Majesty Stationary Office, London.

[19] Mennini, T. and M. Gobbi 2004.The antidepressant mechanism of Hypericum perforatum. Life Sci. 75: 1021-1027.

[20] Miles, R. D., Butcher, G. D., Henry, P. R., Littell, R. C., 2006. Effect of antibiotic growth promoters on broiler performance, intestinal growth parameters, and quantitative 
morphology. Poultry Sci. 85:476-485.

[21] Nidaullah, H., F.R. Durrani and S. Gul, 2010. Aqueous extract from different medicinal plants as anticoccidial, growth promotive and immunostimulant in broilers. ARPN. J. Agri. Bio. Sci. 5(1): 53-59.

[22] Ocak, N., G. Erener, F. Burak Ak. M. Sungu, A. Altop and Ozman, 2008. Performance of broiler fed diets supplemented with dry peppermint( Mentha peprita)or thyme(thymus vulgerus) leaves as agrowth promoter source. Czech J. Anim. Sci. 53;169-175.

[23] Ogbe, A. O. and Affiku, J. P., 2013. Effect of polyherbal aqueous extracts (Moringa oleifera, Gum arabic and wild Ganoderma lucidum) in comparison with antibiotic on growth performance and haematological parameters of broiler Chickens. Res. J. Recent Sci. Vol. 1: 10-18.

[24] Olugbemi, T. S., S. K. Mutayoba and F. P. Lekule. 2010. Effect of Moringa (Moringa oleifera) inclusion in cassava based diets fed to broiler chickens. Int. J. Poult. Sci. 9: 363-367.

[25] Owens, B., L. Tucker. M. A. Collins and K. J. McCracken. 2008. Effects of different feed additives alone or in combination on broiler performance, gut microflora and ileal histology. Brit. Poultry Sci. 49:202-212.

[26] Portugaliza, H. P. and T. J. Fernandez. 2012. Growth performance of cobb broilers given varying concentrations of malunggay (Moringa oleifera Lam.) aqueous leaf extract. Online J. Ani. Feed Res. 2: 465-469.

[27] Richmond, A. C., K. and S. M. L. Mackley. (2000). Herbs and Spices, 2nd Ed . Lorenz Books Anness Publishing Inc., London, UK.

[28] Saeed. J. 1990. Effect of Infectious Bursal Disease on Newcastle disease vaccination in layer chickens. MSc. Thesis. Vet. Microbiology. U. A. Faisalabad.

[29] Saeid. H. D.,Vajeh. F and Shohreh.H.D.2011.Enhancement of broiler performance and immune response by Echinacea purpurea supplemented in diet.African Journal of
Biotechnology Vol. 10(54), pp. 11280-11286.

[30] Sharifi, S. D., S. H. Khorsandi1, A. A. Khadem1, A. Salehi1 and H. Moslehi. 2013. The effect of four medicinal plants on the performance, blood biochemical traits and ileal microfl ora of broiler chicks. Int. J. Poult. Sci.7: 71-76.

[31] Steel, R. G. D., J. H. Torrie and D. A. Dickey. 1997. Principles and Procedures of Statistics. A bio. appro. ( ${ }^{\text {rd }}$ ed.). McGraw Hill Book Comp. Inc. New York, USA.

[32] Subapriya,.R and S., Nagini. 2005. Medicinal properties of neem leaves: A review. Curr.Med. Chem. Anti-Cancer Agents. 5: 149-156.

[33] Toghyani, M., M. Toghyani, A. Gheisari, G. Ghalamkari, M. Mohammadrezaei. 2010. Growth performance, serum biochemistry and blood hematology of broiler chicks fed different levels of black seed (Nigella sativa) and peppermint (Mentha piperita). Livestock Science 129:173-178.

[34] Tollba, A.A.H. and M.S.H. Hassan. 2003. Using some natural additives to improve physiological and productive performance of broiler chicks under high temperature conditions. 2. Black cumin (Nigella sativa) or garlic (Allium sativum). Poult. Sci. 23:327-340.

[35] Wheeler, G. E. 2006. Use of a herbal supplement to reduce the effects fo stress in intensively reared chickens. Ind. J. Indig. Med. 11:78-83

[36] Windisch W., K. Schedle, C. Plitzner, and A. Kroismayr. (2008). Use of phytogenic products as feed additives for swine and poultry. J. Anim. Sci. 86, 140-148.

[37] Zafar. M., A. A. Anjum, M. F. Qamar, M. I. Najeeb and A. Maqbool. 2011. Role of herbal polysaccharides as growth promoters in broilers. Sci.Int. 23:157-159.

[38] Zanu, H.K., J.K. Kagya-Agyemang, W.K.J. Kwenin, F.R.K. Bonsu, E. Antwi and S. Ateni. 2012. Physiological Response of Broiler Chickens to Azadirachta indica (Azadirachta indica) and Akakapenpen (Rauvolfia vomitoria) Decoctions: Performance and Carcass Characteristics. Int. J. Poult. Sci. 10: 730-733. 